\title{
The Effects of Left Stellate Ganglion Stimulation on Left Ventricular Synchrony in Dogs
}

Charles Edward Osadjan

Loyola University Chicago

Follow this and additional works at: https://ecommons.luc.edu/luc_theses

Part of the Physiology Commons

\section{Recommended Citation}

Osadjan, Charles Edward, "The Effects of Left Stellate Ganglion Stimulation on Left Ventricular Synchrony in Dogs" (1964). Master's Theses. 1943.

https://ecommons.luc.edu/luc_theses/1943

This Thesis is brought to you for free and open access by the Theses and Dissertations at Loyola eCommons. It has been accepted for inclusion in Master's Theses by an authorized administrator of Loyola eCommons. For more information, please contact ecommons@luc.edu.

Copyright $\odot 1964$ Charles Edward Osadjan 


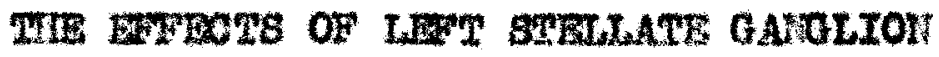 \\ GTTMULATION ON LWP VRTRTOULAR \\ SWICTROAX II DOGs}

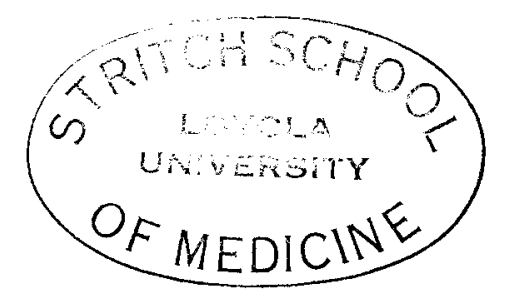

68

Charies Batard osodjan, Ir.

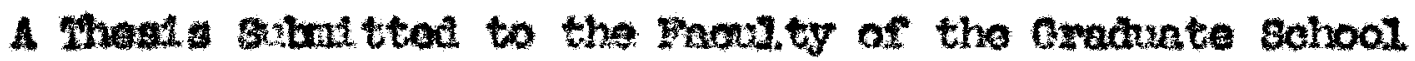
of Loyola thivasaty in partlal Furiument of the Roquitrenents for the Dagreo of Naster of salence

Juno

1964 


\section{LIFE}

On August 11, 1938 Charlos $\mathrm{E}$. Osadjan, Jr. was born to $\mathrm{Mr}$. and Mrs. Charles E. Osadjan in Chloago, IIlinols. Ho livod in Berwy, Illinols where he recelved his olementary oducation. In June, 1956 he graduated from st. Ignatins High school of chicaso, IIIInols as the class valodictorlan after having camed monborahi, in the Vational. Forensic League and the Wat onal Ionor socioty.

The author attendo: the colloge of Arts and selonces of Soyola thivorsity from 1956 to 1960 , and was grantod the dogreo of Dachalor of selenco. Mulle in colloge he was a nember of Wosmann Nological sockety and prestient of Cama Delta chi fratemity.

In 1960 the author began work leading to the Aogroe of Doctor of Medicino at the Striteh School of Modictno and 18 prosently torzinating those studies. The author bogan gradute strules in tho Dofartmont of hyslology of Loyola "niversity in Sortember, 1961 and has combinod these concomitantly with his dootoral studies. Ho is menber of the Student Amorlean Modical Assoclation.

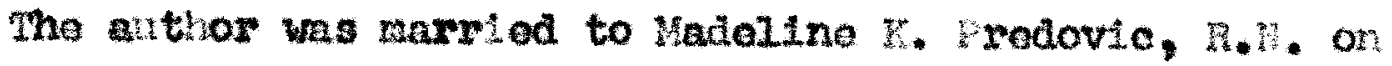
cotober 20,1962 and $1 \mathrm{~s}$ the father of $\mathrm{a}$ son, David feorco. 
Acrorontmentws

The oxporimontel resoarch rosented in this thesis was $y$ unportod by research grant $13 \mathrm{~s}-02705$ from the national Ingtitites of Monl th of the Initod statos Iublic Hoalth sorvice.

The author whos to cor ress his stnoore gratitudo to Irofossor Waltor C. Randall, chatrivan of the Derartant of Iystology of loyola inivorat for his skinful aid in the condict of this rosearch. 
TALE OF COMTR

Chay tor

Iage

I. BACYGROMD OF TIE INTRAVITTRICULAR

SMTIROMY COHC T

Statorent of inforence that symathets cs nodiry ventricular synchrony--The work of Ratcher-The theory of rusole action and the intraventrioniar pressure curve of MIgEers-pathways of electrical oxd tation in the heart--p rosimptions made concoming ventric lax symelurony and electrical conduction-statcont of piroso of thests.

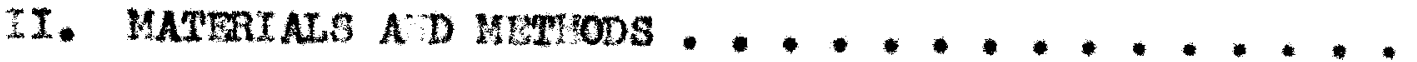

Stateront of anesthosia used and surgery done on first series of dogs-Description of strain cavge arch and 1 ta uso to dotoct misele shortening staterient of anesthosid and instrimentation usod In socond series of dors-Desertytion of gecordings and electrontc equirment.

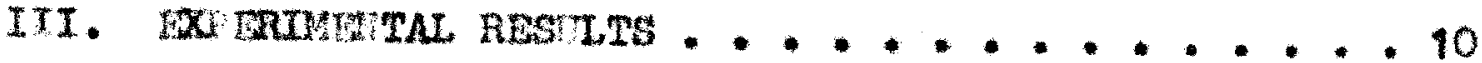

Control records show an in rodicted sequence of musenlar ohortening--Intorventricular so ton bogins to shorton after othor sogrints tostod-An analysis of mise Ins symchrony in the control

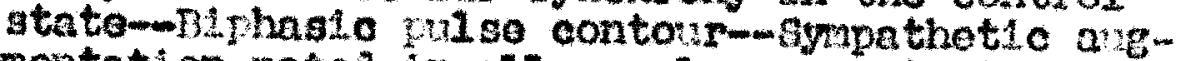
montation noted in all musclo segmonte testodin analysis of mociar syrolirony ding loft steliate Gangilon stiralation-Dofint $t$ on of contraction-pulso interval and 1 ts applent on to the recording obtat nod-1-1ectrical and nom chanical activ'ty of lost ventricle domonatrotod and compred to findings of other rosearchorsmlodification in sogiones of aleatrical act vity W th symathotic stimiation-m - cotromochant cal compling tho at oach segmont st d od-Difsorontial changos of alectromechant cal coupl int thres at the ateferent tost aross inducod by loft stallato stmulatson-observatlons of miso contour durlne control and etimlntion statosmTab lation of ox ortrontal aata. 
IV. DIsCtsgron of Resthos ............. 20

Egsential procautions in use of strain gaugo and intarpretation of data-01 seussion of Iate gxcestation and subseguent shortensine of the interventricuzar soptim-nurthor investileation to mule out the possibility of exparnontal. artifaot-Biphado contracti on wavos and FusP's obsarvation of Inflow and outmow tratim-Blgnifleance of a modifleation of myocardial ynchrory-Preferential pathways of elootrical oproad win avmathotle stimulation-comparison of predent data with that of Inthome.

v. TTMARX

Pvidenoe supports the provioukly undocraented inforenced concerning the ventricular cynoineony conoept-Trpredioted phyalologto ovents alclosed-Conaluston. 


\section{LISw or Tates}

Table

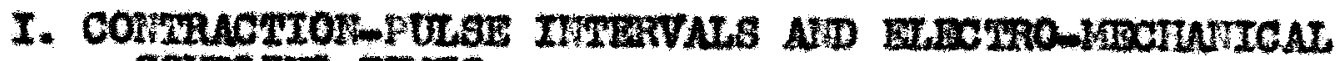
COUPLIno Trans

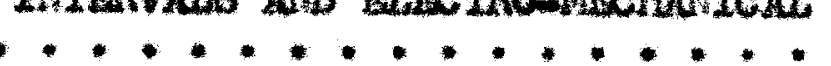




\section{LIEX OF Frothes}

Meure

Page

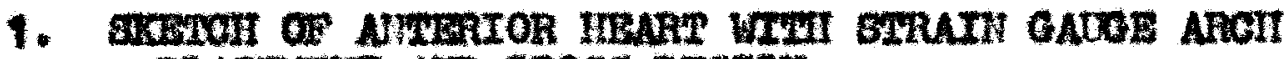

PLACESTIT AND GROBS DEgran

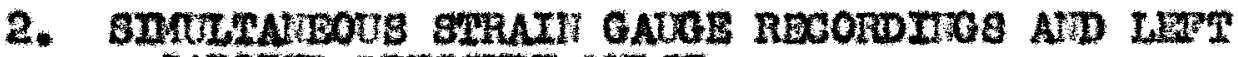

CAROTD PRESSURE PULSE

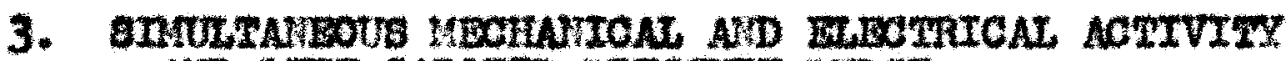

AD LERT CAROTD FRESSURE NTLBE .......... 16 
CHAPTER I

BACKOROUND OF THE INTRAVENTRTCULAR

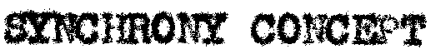

The response of the heart to stimulation by wy of the sterlate ganeilon has been studled by many investigatore over the past century and has led to the Inference recently by Dner and Randall (24) and by Samoff and $h \mathrm{~s}$ co-workers (16, 19) that it includes modification in the aymehrony of myocardial contraction. Ratchor and co-workors (7) denonstratod, by stereoscop1c cinematography, changes in the symchrony of Left ventricular segments subsequent to the injection or lovarterenal. The surmation of individual muscle segment shortening to produce net ventrloular work was firat cloarly described by Miggers (27) In 1927, and he stated that the intraventricular prossure curve "may not be rogarded as an addtion of utimate contraction in phase but as a sumation of rapialy succeding fractionate contractions". Since symathetic stimwation substantially roduces the portod of systole and correspondingly increases the perlod of diastale $(13,17,23)$, an altered synohronis of fiber contraction would sean to be an important influence of aymathetic innorvation in producing 
Increased power and work.

Metseulous measurements of the sequence of ventricular oxcitation have been made, uging oplcardial electrodes, by Lew s and Rothrohtld in 1915 (11), by Wiggers in 1927 (27), and by Harris in 1941 (4). More prec1se pathrays of electrical excitation have recently been traced by soher in $1961(21,22)$. The latter investigator util1zed multiolar aleotrodes plunged into the walls and contractile tissues of the ventricles. Hectrical activity began in the proxtmal taminations of the bunale branchos, spread rapidiy along the endocardial surfaces to the aptoal portions of the septu and pepillary musclos, transmurally from endocardial to opicardial auraces in the midalo and aploal free walls and finally torrard the base of the walls and interventrieular septrom.

It is Important to point out that all of the above desoriptions of alectrical sequential sproad rerresent data obtained from anesthetized animals in the absence of aympethetic stimulation. From these descriptions, however, a muber of presumptlons have bean made. Firat, if it were possible to record soparately the suceessive exeltation of individual segments of mocoardur, it would seem roasonablo to expect s parallal soquanes of mechantenl shortoning. Secondily, it would sean reasonablo to presme that the pattern of electrial excitation as deronstrated in the control state would renain essentially unchangod, as regards the bagle soquence of 
eloctrical axcitation, durine periods of left steliate ganglion stimulation. The facts of the matter are, however, that sequential rocordings of tho contrnetion of various mocardial sogments have never boen mado. It has boen generaily prosumed that the intervontricular soptum contracts eamy in systole, but this has nover boen docmented. The photographic ovidenco of yuf (12) and the strain gaugo data yocovded from chordao tendineae by Balsbury (15) havo addod sowe data to the concopt of Intraventricular sychrony. Wher's high apoed photographs demonstrate the asymchrony of the ventricular seguents inaludine the papillary macle action, inflow and outhow tracts but do not includo an attempt to demonstrate any alterations associatod with synpathetic augsentation. Swlisbury has recently attemptod to measure the termoral relationaly of papillary mase contraction wth the intial fiso of intraventrictiar pressuro by measume ehoxdas tendinoa tonstan. Io Interprots his data as indieating that chorda tendinea tonston develops at the sure tino as the indinl upstrolio of the intraventricilar prossure. Thls would tend to conflict with the data of Puff and Rugimor (14) wo toech that the popillary muscle bogins contracting before all othor ventrioular macie segtonts. However, Salfsbury nocorted his data at a nover syeed too slow to allow for accurato menaurenent of the minuto time alfroroncos which wald be expected on such rocordings. This is indood unfortinate because such measurenonts properiy 
made with a high speed recording apparatus would contribute much to the presont understanding of vantricular synchrony and cardiac dynamies.

In the prosent Investigations, a sertes of mall strain cauge arches in conbination uth pin eloctrodes woro positioned at several st tes on the left ventricle of a number of dogs in an attempt to noasure the sequence of mechanical shortening and eloctrical excitation. The data denived chring control porlods wil be contrasted th that demived during syapathotic stimuation. In this way the above nentioned inferences and prearmptions can be tested. 
CIXPTE II

MATESALS NDD IETHODS

In a group of nine nongral dogs $(6-23 \mathrm{Kg})$ anesthetized with Nembital (Nontobarbltal sodium, 32 ga/ke) a left thomecotony was torforned and tho third and solvth wibs renovod (Sorios I). A unfpolar electrode was loowed atcond the caudal pole of tho laft stallate ganglion and a perloardial cradie construtotod. Three sR-4 BLII strain gauges (nodified Walton gauges) were sutured to the antemior oploardiun of the left ventricle with 40 surgical o13. All gatges wore positioned yomondiculax to the interventricular septum (Higure 1), one (no. 1) at the base, a second (No, 2) at the apes and a thitrd (Fo. 4) approxinately midway betwom the abovo two. A fourth gauge (To. 3) to be degeribed in greator dekail later was numged into the Intervontricular septum rather than suturod in posftion on the enloardiun. A sogment of aprosinately $1 \mathrm{~cm}$ of myocardiun vas containod botweon the polnts of attnchumt of each strain gaugo arch, and the suthres of gauges tos. 1 , 2 , and 4 ponotrated to a depth of approxintately 3 ath. The relative postion of nlacexant of the strain gauge arches as wall as their Erosa destegn wal bo noted on Mgure 1. 

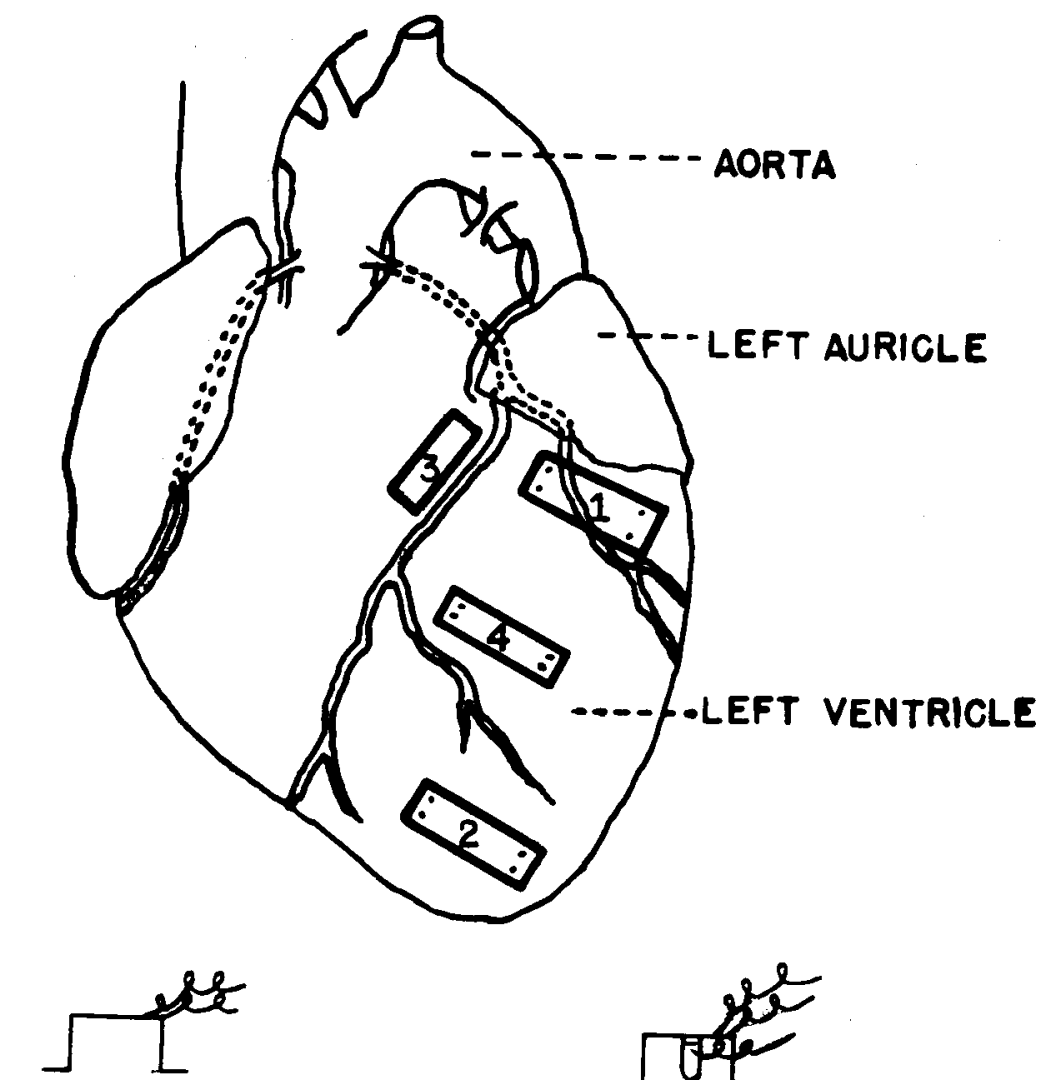

VENTRICULAR

GAUGE

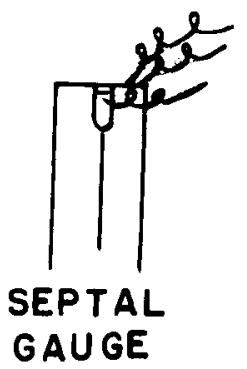

TICUNE

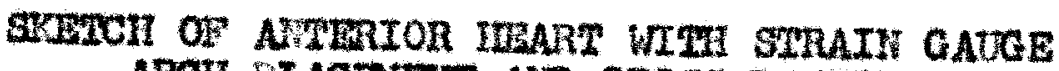

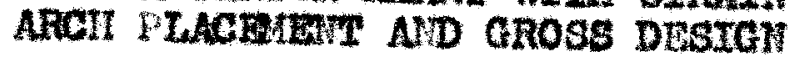


In a socond group of elght dogs $(7-21 \mathrm{Kg})$ anosthotized W th chloratose (i.v. $100 \mathrm{mg} / \mathrm{K}$ ), pin electrodes were positionad between the legs of the atrain gauge arohes to record the glmul taneous mechanical and electrical aotivity in each region. In this mecond group of dogs (Serles II), strain gauge arch No. 4 was not applled to the experimental proparations. The strain gauge arch used to record activity in the interventrioular soptran (No. 3) in both serles I and series II wes conotmoted in an E shape as dagromod in Figure 1. the lateral prones, which were shappened and $1.5 \mathrm{~cm}$ in longth, recorded the mechanteal sctivity while the midale prong sorved as an olectrical plak-up eleatrodo. The lattor was insulated frem the renainder of the untt with neable epoxy resin. The prong 1 tself wa Insulated excopt for the terninal 1.5 man with several coats of Insulating varnish. The prongs of this unit were pushed through the anterlor cardiac wall bestde the antertor deacending coronary vessels unt1l posttioned in approxInately the center of the thlolness of the intervontrioular septum at a point approxinately 2 cm fram tho bage. At the conelusion of each experiment, the heart was exaritned to be certain that the legs of the gauge ware in the anticipated post tion. Murthernore, to be certain that only septal aotivity was reoorded by this unit, a right ventriculotany vas perfornod and the und ditectiy implanted into the interventricular septuan of 3 dogs (Series III). The records so obtained vere 
compared with all others to mule out artifact in the latter.

simultaneous recordings of the eleotrical and contractile events, together wth left carotid arterial pulses were recordod on a Crass Model $5 \mathrm{~A}$ polygraph at a paper apeod of $100 \mathrm{ma} / \mathrm{sec}$. during control periods and periods of stellate stimulation. Stimulation was accomplishod wh a Gass Model 85 isolation stimulator at 10 volts, a frequency of $5 /$ soc. and a pulso duration of $5 \mathrm{msec}$. Since the proper interpretation of the data to be obtained using the above recording apparatus demandod a rapid responge time of that apparatus, 1 t was deened necessary to measure the response time of the intogral recording systen. Ths becmes obvious if one considers that a critical neasurement of the type to be presented in this thesls involves the ability of the recording apparatus to rapidiy respond by means of a pen daflection to rapid changes in the misele segment length.

When tension vas instaneously released from the legs of a strain gauge aroh, the resronse time before the inftial pen derlection was measured to be less than $1 \mathrm{msec}$. The Mse time of the van deflection was measured to be $7 \mathrm{msec}$. for 60 per cent of the total anj21tude of deflection. The frequency response of the strain gauge arch was deternined to be in excess of 250 ops. The frequency reaponse of the polygraph unt it self is Iinear plus or mims 5 por cant from $D C$ to $45 \mathrm{ors}$. In viow of this, the recording systen was consldered to be more 
than adequate for the type of measurenents which were to be made. 


\section{CHAPTER III}

BXK BRTMTHAL RESTLTS

Migure 2 shows simul taneous recondings of the left carotid arterial pressure, mechanical shortenine of a segnent at the base, the are and the Interventricular soptum of the left ventricie. Control recorts are shown at the left and responses to left stellate ganglion stimulation at the right. The oplcardial segment at the base was oloany the flrat area to shorten. It will be noted that in this oase the lattor 18 twie of both the control record and the record of sympathetle stimulntion. Shortening at the apex followed that at the base by 12 msec. In the control and by 5 msec. In the augmentation record wh110 the interventricular septum was the last of the throo segnents to bogin shortening. The onset of shortening of the interventrloular septum occured 5 mseo, after that at the apex In the control tracing and $3 \mathrm{mgec}$. thereafter in the augnentation tracing. A total of 50 soparate masuranents similar to those denonstrated on page 11 wero made usine the 9 antmals of Sextes I. Of these, during control periods, 20 shoved initial shortening at the apex, 23 at the base and 7 in the area between the brse and apex. The time Interval between the on- 


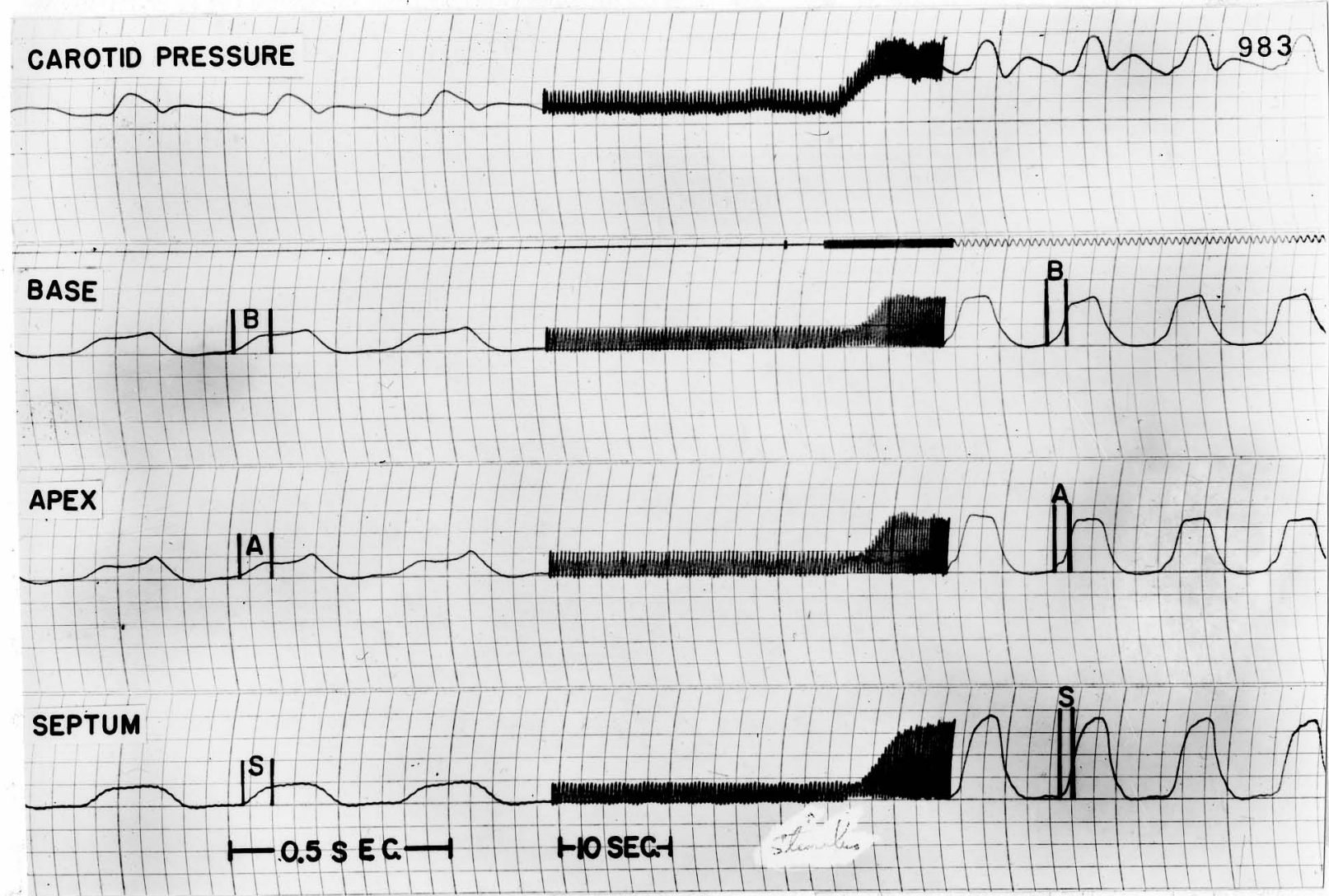

\section{Futre 2}

\section{SMULTMWOUS STRATN OAUCE RECORDTIOS} ADD LET CAROTID PRESGUTS FULSE 
set of shortening in the firat sogment to contract and that in the last ranged between 10 and 60 msec. With a mean of 21 msec. Many of the contraction julsos wore biphasio showing an Initial unstroke followed by a plateau or brifer relaration which was in tum followed by a second upstroke.

A2.1 sogments in Higure 2 rosponded to symethotic stimulation with a marised augnontation in force of contraction, and heart rate inereased from 168 to 246 beats per mimute. The artorial pressure pulse showed tyroal augmentation response Wth an inorease in mean prossure from 125 tm the during control portods to $163 \mathrm{~mm} \mathrm{Hg}$ diring stimulation. The sast traco roveals dramatio alterations in the contont of the indsvidual pulses together wh the increase in force. To the author's knowlodge, this is the firgt desonstration of augmentation in the force of contraction of the intervantricular septun durine symathotic stimuation. The alteration in individual pula contour Include a much more raptd rate of mascular shortening, as weil as longthentrig or relaxding, togethar with a roduction In the total duration of the oyole. It I s interesting also that a sharp $\mathrm{M}$ se in the carotid artorlal blood prossure is wall established constderably before any alterations in the force of contraction appoared in the test misclo sognants. It is cloar from this that the strain gauge archos wore nost 11koIy not positioned on the segments of the ventrloular nyocardium Which wost rapidiy rosponds with an increase force of contrac- 
tion when a symathetlo stmulus is applad. It is also poss1blo, however, that inproved aynchrony of contraction of multiple macle sognents could Induce a more prompt alovation of intraventricular pressuxe with 11ttle or no alteration in force of contraction by each Individual segment.

The intervals designated by the letters B, A and $s$ in F1Gure 2 represent the tine Intarvals betwoen the onset of shortenIng in each Individual mselo segnent and the inftial unstroke of the arterial pressure pulse (contraction-mise interval). The segment ahortening first has a longer contraction-pula interval then those wich follow 1t. Since theso intervals pogsess a comon reference joint (intital wistroke of arterial pressure pulse), they indleate the sequence of shortaning, as vell as a moasure of symohrong of shortening. The contractionpulse Intervil of the bese in the control portion of Figure 2 1s $75 \mathrm{wsec}$. and that of the septur $57 \mathrm{msec}$. The difference betweon these two values is the time interval between indtial shortening in the flrst and last segments, in this case 18 msec. The corresyonding values during stimulation are $41 \mathrm{msec}$. at the base and 32 msec. at the septum for a dufference of 9 nsoc. Thus, by two different neamurements (the sucoessive tImes to onset of msoular shortening, and the contractionpulse interval) it is cloar that these three separate masele sogments contracted more synchronously diring laft stallate ganglion stimuation. 
Wharoas the strain gauge arch Isrod to the musclo sogment at tho base of tho hoxt showod inftial shortoning in approxtnataly one hals of the ststy control tracoa, It revoalod Initial shortenting in 49 of the 50 traces during symathotle stimulation. The interval botwon the onset of shortanting in the first aroa to contract and tho last to contract during stallate stinulation ranged botween 2 and 35 usec. vith an avorage of 12 nseo. as compered with an avarage of 21 meoc. during control. portods.

In figuro 3 both the aloctrioal and the rochanical act:vity aro 111ustrated at the interventricular soptum, tho aper. and the baso of the left vontriclo. Tho carotid artorlal prosstre is also shown. Sequential natterns of aloctrical cxcitation and nochanteal ahortontne wore dotemined, and coupling times botwoon the electrical excottation and onsat of mochunteal ahortaning wore mearurod. While the sequonce of elactrical excitation in the contral traco (left portion of Figure 3) conparod favorably wth the rosilts obtatnod by llarms (4) and by

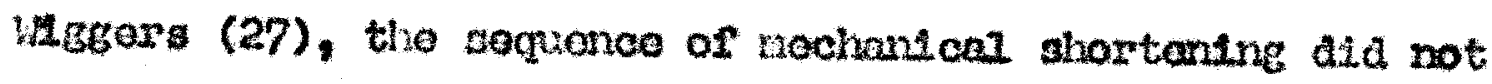
sollow tho sano soquential pattom. Dito to the location of the activo portion of the septri gange in aproseinatory the conter of tho thick muscle nass of the soptra, considerable doviation from the tine of axcltation at the soptal endocardira is to be oxpoctod. In nany axporinents oloctricar axeltation in this portion of the soptra occured several millsoc- 
onds after it occured at the other recording points on the a orz and baso.

In the control portion of Irture 3, olectrical activity ameared first at tho se tal olectrical recording point, arproxinately 5 mseo. Iator at the apex electrode and 10 msec. lator at the base eloctrode. The interval betwoen alectrical oxet tation and mochanical shortoning (oloctro-mochanical coupIng tine) was 30 asec. at the soptra, 25 maeo. at tho ares and $20 \mathrm{msec}$. at the base. Comparable data derived from nulses recorded sust a few aconds later, but during stallato atimnlation, show that olectrical activity first appenred at the base alectrode, followed 10 nsoc. Iator by activity at tho apex and 15 msec. Later at the soptal oleotrode. These observations are shown on the flgure on page 16 by a hortzontal Iine extending from tho strultancous ordinate on ench of the electrial activity traces. In both the control and the stimulation poxtions of the rocord, the tine interval from the ordinate to the Intial deflection of the electrical trace of the base oloctrodo was latd off, and an sdenticle Ino dram beneath the traces of area and soptal aetivity. In the control records the base oxctation clearly followed both apex and seytrm. Howover, in the stimulation record it clearly procoeded both. Coupling timos during atimulation ware 25 msec. at the soptum, $15 \mathrm{msec}$. at the apes and 6 msec. at the base. Tms, it is cloar that tho soquence of 2 intsal excitation was altored signi- 

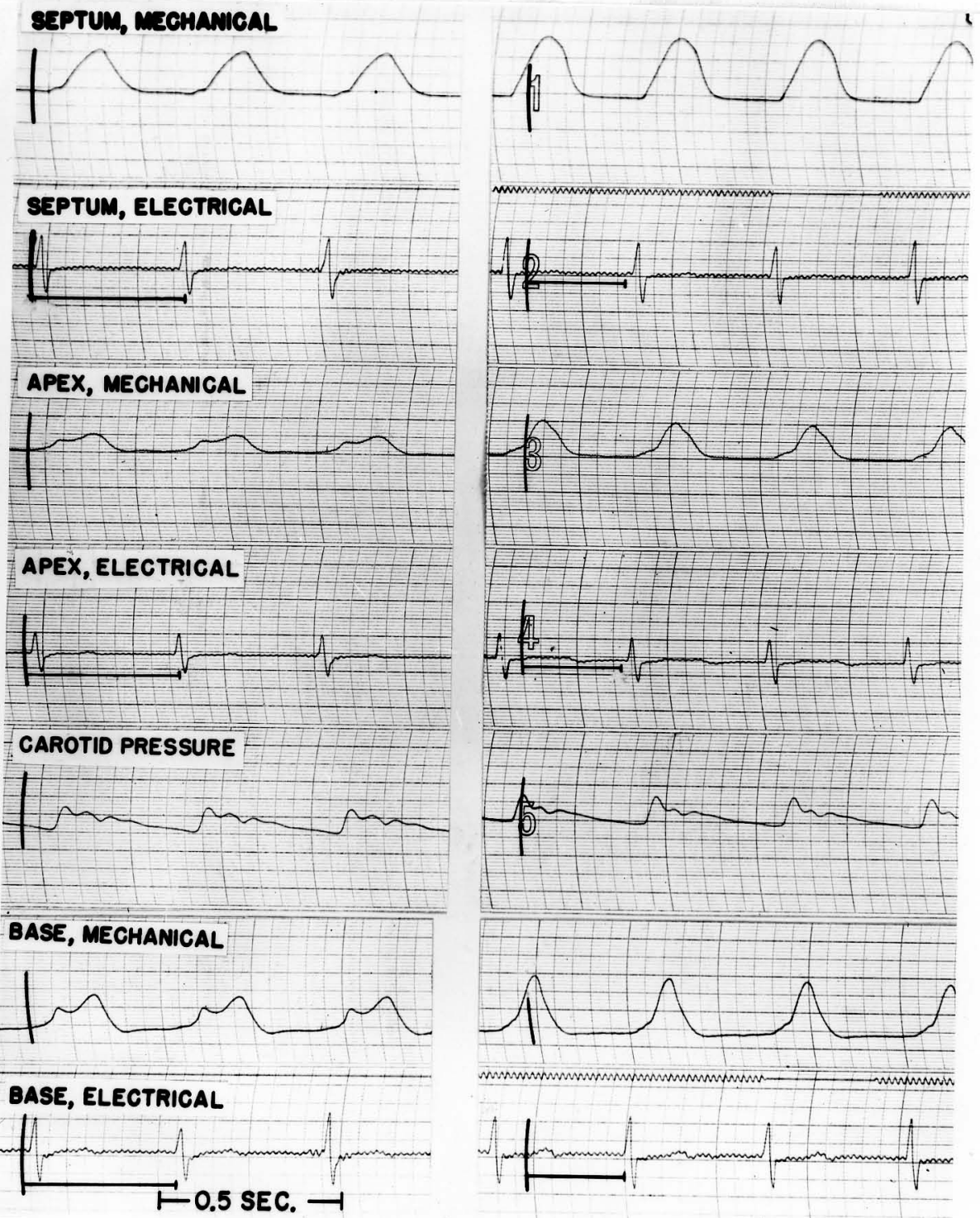

\section{Fours 3}

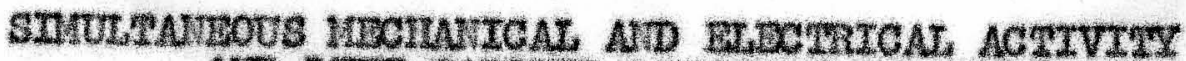
AD LEV CAROTID PRESSUR PULSE 
floantly during sympathotic stimulation, and tho olectro-nochinloal coupline tino at the base narkedy shortoned. The lattor observation vas invariable at the base but not at the soptu Wero data fron all oxporimonts rovoals an average longthoning of the olectromechanicel coupling the from 25 mase. In the control atate to 34 nsec. Auring stolleto stinulation. As 11Instrated in Figuro 2, the interval betwoen tho ansot of ahortening in oach gyectfic ryocardial sogment and the twsving in carotid prossure decreased signifloantly during steliate stimuation. It is also clear that marisod augnentation in force of contraction occurod in ow of the sognonta during stimulation. Carorul observation of the Individual pulse contour besore ard during atimulation reveals im ortant ohanges, particilarly in the aper and base regtons. Whozens both of these reglans show biphaste curves in the control portton of the figure, this $1 \mathrm{~s}$ constaorably loss evident arming left stallato ganglion stimulation. Tho onget of controction is gonornlly sharpor and moh more easily doteminod during stallato ganglion stifrulation than during the control portods.

Table I on page 18 presants in a tabular fashon a sumnary of the data obtained froa sentes I and sortes II groups of animals. The horizontal colum roprosenthing sories III w11I be comsented upan in tho following chrpter. It should be noted from the tablo that the Contraction-miso Interval is groatost at the base of tho ventricle and lanat at the Intorvantriouzar 


\section{DADEE I}

\section{COTMACTOHW TLSE TITERVALS AMD \\ BT.DCTRO-UEOLAUTCAL

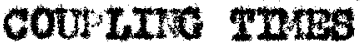

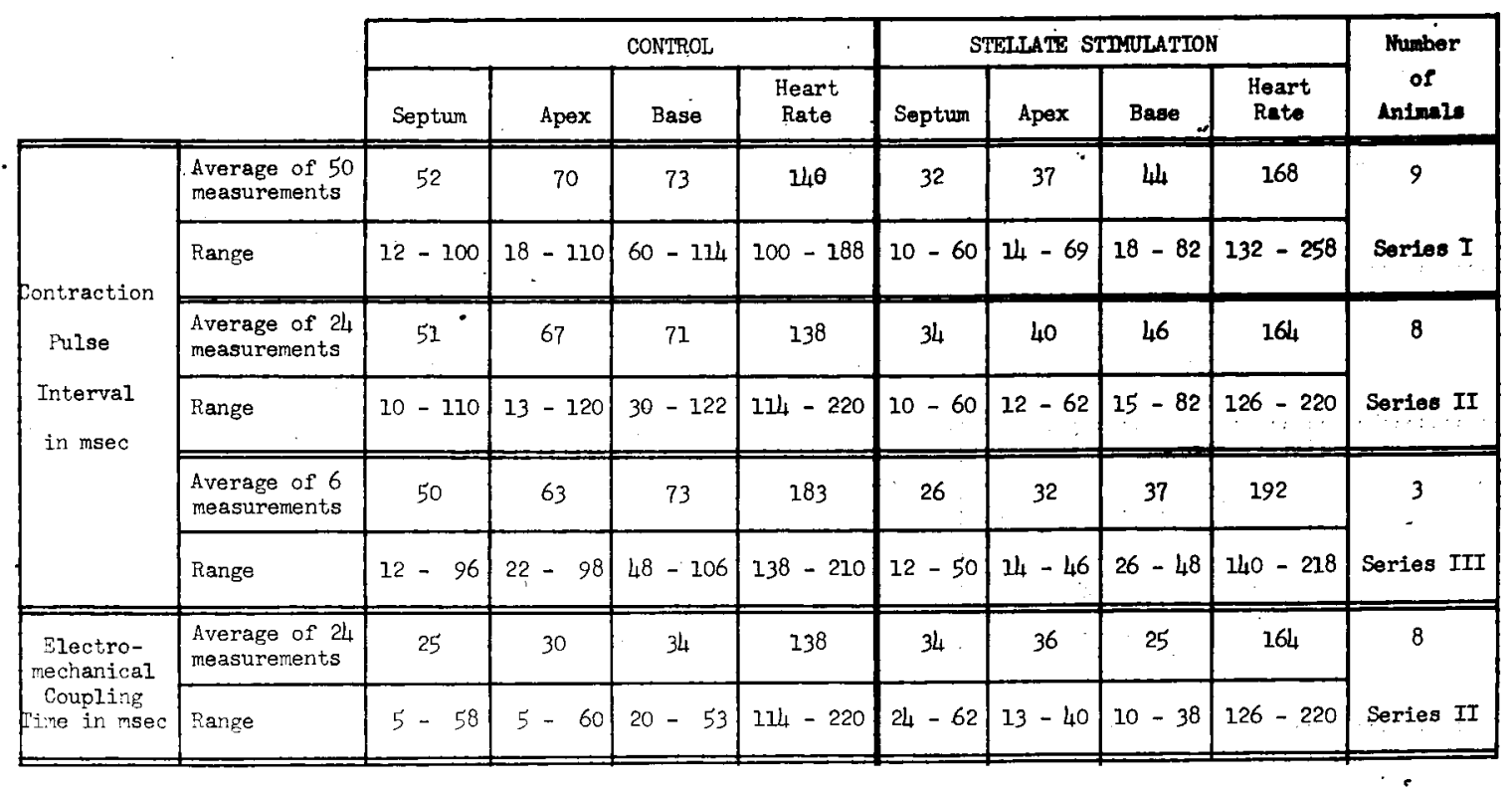


soptra. This is twe in both the control and tho stimuation sets of data. The average afference botwoen the Contractionivlso Intervals of the base and the soptim is 21 msec. In the control data of Serios I, 20 msoc. in somes II and 23 msoc. In Sorles III. Tho ropoctive avorago date during stellato canclion stimulation is 12 nsec., 12 asoc. and 11 msoc. Tho

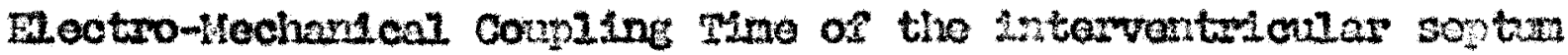
increases rran an average of 25 nsec. In the control to $34 \mathrm{msoc}$. In the stimulation date. A similar increase occurs at the apos. Howevor, the averago Hoctro-kecharscal complne Ino of the baso docreeses fros 34 naec. In the control to 25 insoc. in the stimulation data.

Becauso of the largo mabor of noasuroments which wore made, only the averages and the vango of opread of the individunl noastrenents could convoniently bo included in Taule I. Hovever, the date vas subjected to statistical motiods and the differances noted in the table were shom to be stgnimcant vith the pever excooding 0.04 . 
CIL TER IV

\section{DIscussron of ResuLts}

To the author's lmovodge, multple rocordings of shortarIn in ind:vidual myocardal somonts havo not provionaly boon analyzed in the marner roported hore. Tho author is woll atere of cortatn essantial precations in the use of, as well as the hazzards in 1ntorpretation of, data dontved rran strain gange archec stitchod to the oplcarditu $(2,3)$. Strict attention was patd to tho $21 \mathrm{x}$ attackment of each $12 \mathrm{mb}$ of the arch to muscle, and offort the made to apply the strain eare arch in the sane relativo postions on och heart. It is amphasiged also that no attempt was made to quantitate or convare force of controction in alfforont hearts. Attontion is directod, howover, to altarations in consocutivo trecos in a given aperinont bofore, durine and aftor stellate stsmiation. Al.teratione occur vithin a period of a fou soconds as a reaut of the experinentol procodure, and traces progressively return to control consigurations rollowing cossation of the procedure. Thus, we have constderabie conflance in the rellablilty of the records rre sontod. In spito of tho obvious tochntenl difficultses in soparately but gimultanoously rocording contrectilo phonomene in soveral afferent pycardin soguents, the signiflcarce of 
such measurements once conploted compelled this anvestigation. The vantmlcular unll is compsed of three baste layers of nuscle fibors (14). The contral, or constrictor layer, is a thick muscie mass bounded intomalsy by a thin obliquely omanted layer of endocardial musclo esbers and extomelly by arother oblique layer of entoexdal zuscle fibers. The two obltque layers are ortented approstnataly $90^{\circ}$ to one another In the plane of the ventriovier surfoce. The nbors of the constrletor Iayer 110 at approrinately $45^{\circ}$ wt the oblique layors in this lara. Tha Individval lavors shou moh intormingling os sibars, and they aro, hence, not as distinct as might bo inforred from the abovo description. It is understandablo, thon, thet then strain gauge arahes are sutured to the ontcorditu as was dome hare, the recom roprosents the sumation of total vector forces between the points of attachmant of the arch. Furthomore, it is concalvablo that rotntion of the stanin Eauge archos to a post tion paratual to the

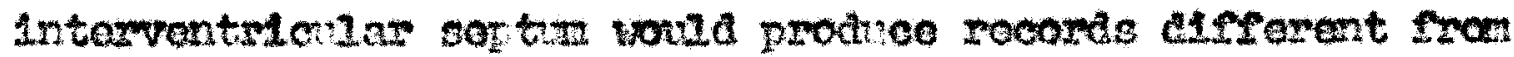
those roontod hare. The latter applies also if the arches sore to be cymaled by means of deer penetrating sutwres. Al though the ondocaratal. surfaces of the soptur are undoubtedy the first rocions of the ventricle to bo axcited, constaorablo tho may olapse beroro tho intemor muscle zass of this stmeture is activeted. Fenco, it is undorstandabie that the septun was the last of the unlts to show gross shorten- 
Ing. This oxplanation can be amilfiod by the further obsorvation that nost experinents show an increase in the counling tino at tho sortum dining stollate stimulation with a conconitant daconse in conling time at the othor test aroas. Ihis suggests a praferential modifiantion in coxeltability of indiVidual contractilo olenents during symathatic stimulation. prasumably rolated to a differential distribution of postganeILonic teminals in hoart teswo.

Further inveatigation was docaed necessary to mue out tho posasbility that the late excltation and subsoment shortoning of the interventricular soptwa obsorved during the course of the experiments comprising series I and sortes II was artifact. When a mght heart by-raas puray watilized and tho Fight ventricle incised so as to oxose the interventricular soptum, the soptal cauge was directly Implanted Into the soptin of three dogs (Sertes III), and the results obtainod showed sine Intervala 1dentiale to those obtained by the nothods describod in the previous chapters. Thus, the rocords prosonted in the foregoing chaptors of this thosis can be attributed to the activity of the intorventrionlar soptia and not to the aotivity of the anterlor myocardsun through wheh the septal gavge intt was plunced in Saries I and Serlos II. The intelal shortening at the oricandial ourface of the base of the left ventricle in approxinately ono-hale the con-

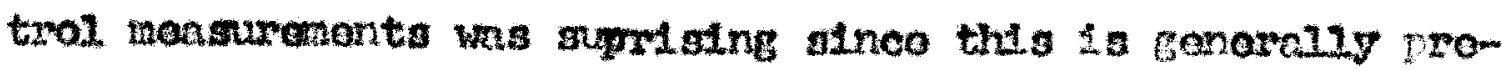


suned to be the last portion of the hoart to be archtod $(4,22)$. A plot of ventrualar oficardal potontsals $(11,27)$ povoals the ourliest oseltation occurs in the contar of tho trabocular rogian on tho artorto surface. surround:ne the segion aro points successively activatod and extanding down toward the aver with simutaneous, but anvarenty slower astenston toward the base. The biphaste nature of the contract on waves $\mathrm{CPE}$ ures 2 and 3) fremently suggested that one portion of the batto shortenod caxly ulle anothar portion bogan to shorton much Later in tho cycla. A fow coreminanta, in which two atrain gauge arches ware slacod on the base, one close to tho septra and the other at the sane lovel but 2 on laternl to $1 t$ have tanded to conring this observatlon. Furf (12) has photow craphed the normaliy beating heart at 1,000 franes per second and subsequentiy projectod the fin at 24 frames ner second, thus achloving a 40-fold alow motion roprocitotion. In this marnar, ho described Int that contraction of the inflow tract followed by contraction of the outhow tract of the vontricle. In Vlow of these observations, the observations noted carlion In this theal that the intervontricular soptim to the last of the soments tested to shorton is qute reasomable. The soptum ocmoses the modtal. wall of the outrioy tract and, this, con be epocted to begin contrnotion aftor macle segments wheh 130 latoral to 1 t and in the vantricular inelow tract.

It is probable that one 2 inb of the enLardial strain 
gaugo arahes was riscod on the lnmow tract wille tho other was ottachod to rusche corrosire tho onthou troct, thus romuting in b1 hasio contrcetion unves rovontod in nany of the traces. If this ntrovas to bo trin, tho tondancy for the alsappoarance of the uphasio contour drung staliate stinulation can be intomratod as add tonal ovidonce for insovod vontuloniar symahrony with anapathotic stimulation.

Ao sugeostod by samore (19), pressume in the heart is producod by the sograntiel and prograssive dovelomment of tanaton in cortain portions of the myocurdiun whilo othor portions rouatn uncontracted. Whon onch of tho pyocardial begurents contract Indopondanty of any procroned sequence, 11 thlo or no extomn work is accompliahed. On the contrary, when the ryo-

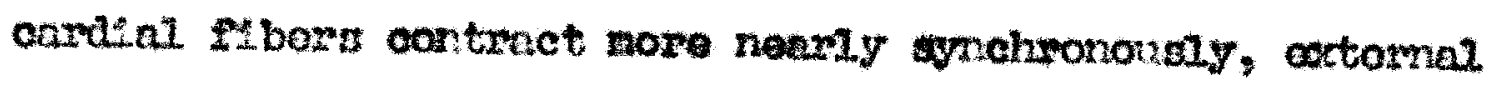
wort ahould bo Inhanced. Ints 13 not to argue that all porm tions of tho vontrienlar macilatiwo vil achievo an iltinato veali of ofrictoncy when they contreot simlianooundy. Indoed, such an explosive dovalorment of tonston would not accornulah tho purnoses for wheh the ventricle was destenod. Fowover, the present observations document the inference that tho vari.ous portiono of the vontricles do ontrect nore annohronouxy, and such phonomona uxdoubtodiy contulute to the nore rapid wiso and sez, togother with highor moxinal rwessures attatnot during symathotic stimuation.

Conduction veloct tos botwoen bro rocorasue aloctrotos 
have boan shown to bo increased In both atria and vontricles, as well as across the $\mathrm{A}-\mathrm{V}$, innetion, as a rosult of electrical stimulation of the sympathetic cardiac norves and by ingection of at ther 1-norepinophrine or 1-opinephrine (1). Apparent1y, howevar, veloolty is not markody increasod in the specialized

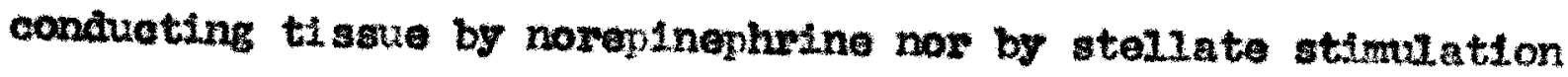
(25, 26). Thus, nodest ohanges in the aymohrony of oontraction of distant portions of the myocardiun may be accounted for on the basis of altered conduction veloeitios. However, the aramatic and consistant ahift of initial excitation to the baso of the heart cannot be cocounted for in this way. Thore secus to be no altemative to the assumption that the exolting impulase "short-cuts" by wowe al ternate "preferential" pathray to this area during stallate atimulation. On the basts of the data Dresented in the foregoing chapters, it cannot be mied out that the early aleatrical excltation at the vantrioular base was associated with an etople focus of nodal activity. Indeod, it has been observod by the author that wen the stollate gangI1on $1 \mathrm{~s}$ sturulated in non-vagotomizod dogs shuh as those used In this investlgation, the mot ahows ovidence of etoplo nodal activity nore frequently than in vagotoulzed preparations. The location of "proforential pathrays" from nodal tissue to tho base of the ventricles is not alonr, but such channals seen to bo opened through norvous atimulation, porhap a though $100 a 1$ Liberation of norepinophrine. Kent reported that the A-V node 
and Its puxifn;o brunches are not the only connection botwos the atrita and vontricles. Te doseribod accossory conductson pathways composod of ordthary mocardial colls, the "wudie of

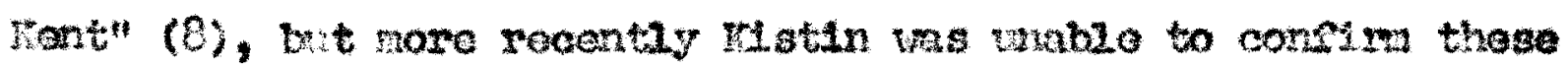
obsexvations (9). Disorete anatamienl nccossory pathrys havo, howaver, beon doscribod in tho hman hoart in pationts wo masfest wolf-parkinson-int to syndrome (10).

Durine control exporinouts, the time interval botwon the onset of shortendng in the flrat area to contract and the intorventrioular soptou, Whah was tho last aroa to bagin shortonIne, varted botween 10 and 60 msec. Wt th andrago of 21 msoc. Dixing left stellate ganglion stimuation this tire intorvi docreased to an svorage of 12 msed. Wh th range of 2 to 35 rasce. Itus, as previloualy inferred $(16,24)$, left ventricular contraction becomes more nearly aymohronons during stollato stimulation. This unloubtedy contributeg to the nore rans rise shase of the ventricular presenxe pulse durting stoh oloctricul stirnatation (18).

The shortendng of the vixhous negments of the lest ven tricle in this group of experiments occurs at a tzmo in tho cartiac cyole which would corresnond to a corbination of the apox-to-base shortanting and the change in crosa-soct onal arec as reported by Mawthame (5). This Indastos that the mothods orployed in the prosent atudy aro non-specte as recards the difoction of the dumensional changos of the vortriclo, ivt thoy 
tast rather tho sopuoneo of shortering, efthor oncr-tombase and/or ctrcunferentind, in the wriou segmonts of the ventricle and the motifleats on of this sorvence diring symathetic augrentation. 


\section{Crustan $v$}

\section{gIMARX}

Unti1 this tine no alrect neasuranents of the synchrony of shortoning of Individual myocardial macio segnonts have been avaliable. There have been, howover, as notod in the previous ohapters, a muber of Infarances put forward in the sciontiflo 11 teratiwe whl ch suggested that the heart noranlly funetIons in an anymohronov fashion. Furthemore, it has been speculated that a modiflcation of the amohrony of mpocardial. contraction could explain some phenomena assoctated wh sympathetle augmentation. Katchor and his assoelates denonstrated by means of alnematography that the ventricle contracts nore noarly symchronously following the injection of levarteronal. such a photographic denongtration, howover, is not subject to careful quantitative amination of the time Intervals botween tho onsot of shortening in varlou myocardal sogments and, hence, is not entireiy adequate to subatantiate the inforences wh oh ware made.

The primary purpose of the research incomporated into this thests has been to docment the symchrony concopt of vontricular dymanies as being true or false. It has been shown in the 
foregolng ohapters that the tayocardial segments do, Indeod, nomally shorton in an asymahronous faghion. Durlng loft atallate ganglion stimulation, the maclo begments tented began shortening in a moh nore prealotable, as wall as synchronous mannor. It should also bo caphadzod that to the author's lanowledge an analysis of the intorventrloular septru suoh as has been prosentad in this thosts, has novor been prosontod. Fuxthentore, excepting "ufr's photoghaphte ovidence, the above annlyals is the rirst to tentativaly augeat tho oarly contraction of the ventricular inflow tract followed by the contraction of the outriow tract.

The measurenents of the sequence of aleotrical cxaltation of vontricular sogmonts presented in this thosis agree, at least in the control state, wh those of mmerous other investlgators. During the porlod of aymathetse stimulation a peculiar pattern of Imvulse spread vas frequentis noted. Such pattems disclosed the early appearance of the loctrical potentsal at the base of the vontrlcle followed by 1 ts appearance In the othor sogaents. This was interproted as ovidenoe for the existence of "preforentsel" pathways of conduotion. since no alectrocardiogran was recorded, the possibility of an otople focts of nodal aotivity uithin the ventricle could not be dom Intely miled out.

in concluston, by means of proviaing afeniflcant ovidenco for wht wore hitherto tontative suppositions, the primary pur- 
pose of thi invostigation had boan fulfiliad. In addition to the fulfilment of tho primaxy goal, sovern uniredictod ontities wore serendipltously rocordod and later discussed. 


\section{ETBLIOCRAPIY}

1. Drooks, C. MCC, B.F. Horman, E. 2 . Suculing, and 0 . Ortas

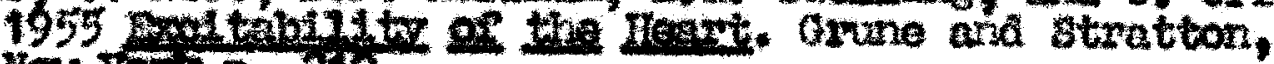
Hew rork 2.219.

2. Cotton, $\mathrm{H}$. de $\mathrm{V}$, , and $\mathrm{z}$. Bay Duroot meesurenent of changes in cardiac contraotilo porce, relationshlp of buch

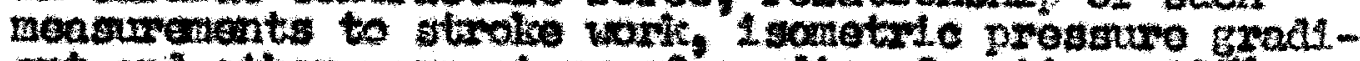
ent and other parameters of oarliac nuotion. 195 A. I. Phyador., 182: 122-134.

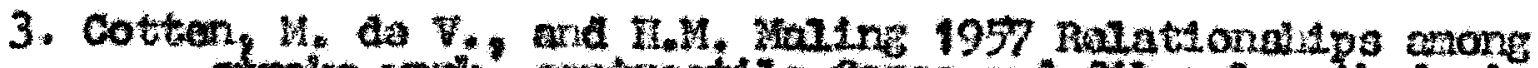
atrolse work, contraotsio force ard Ptber length durring changes in ventrialar function. M. J. Thetal. 189: $520=526$.

4. Inrris, A.8. 194t tho spread of arctation in turtio, dot,

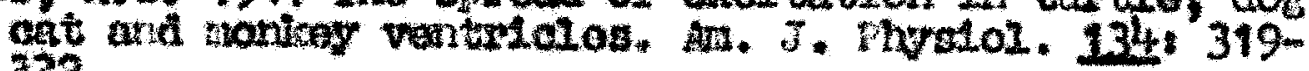
332.

5. Iawthome, E.W. 1961 Instanoous atnensloral changos of the left vantrialo in dogs. Circulation thos. 2 110-119.

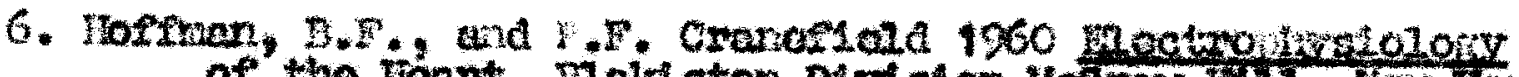

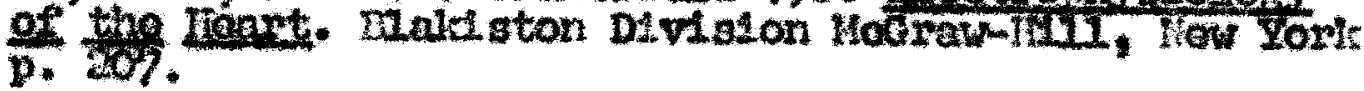

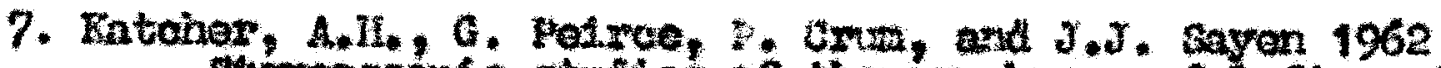
Btemeoscopic atuates of the symoinrony of left vontricular controctiot. (Nbst) Fea. Froo. 21, 131 .

8. Ront, A. E. 8. 1893 Researehos on tha structruxe and funotion

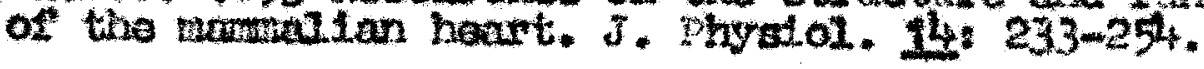

9. Wstin, A.D. 1949 Observation on the anatony of the atrioventricular commeotions in nomal humen haarts. An. Iloart J. 32: $849-867$.

10. Low, N., D. Sodl-Hallares, and C. Frtadand 1903 A higtopathologso atudy of the atrioventrioular cormunscations

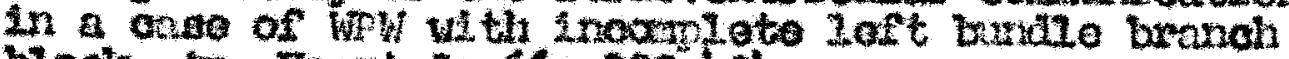
block. An. Hoart I: 66 : 399 -104. 
11. Lovis, 3. , and $\mathrm{H}, \mathrm{A}$. Rothsohl1 1915 the oxct tatory process In the dog's hoart. part II-The vantriclos. hil. Trans. Roy. soc. D. 206: 181-226.

12. Wuse, von A. 1960 DLe momphologte des bowogng sablaufes dor

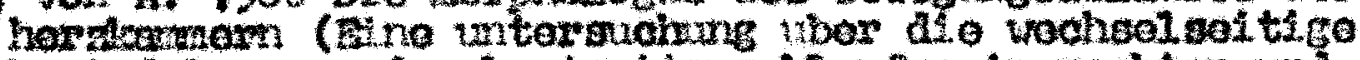
beoinfulusenug des lontrationgubiaufos in rookton und Iiaken ventritrel). The morphalogy of the couxise of conm traetion of the caxdiac chrabors (As Investigation of the treesprocal influences of the contrectillo procoss in right and left ventriclos). Anat. Anz. 108: 31:2-350.

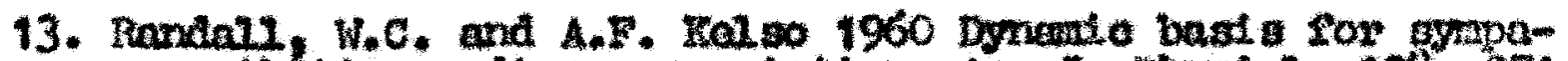
thot to carbise mugantation. Ar. J. Hystol. 193: 971974 .

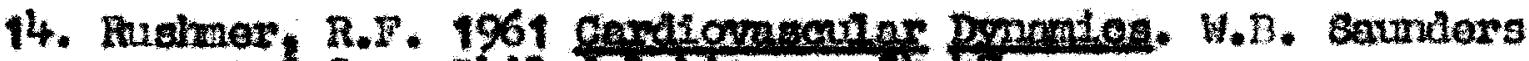
and co., Phindeipkia, p. 34. 47 .

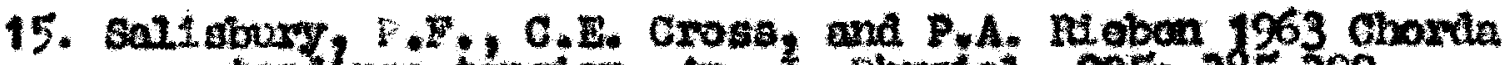
tandinne tonsion. Am. J. Physto1. 205: 385-392.

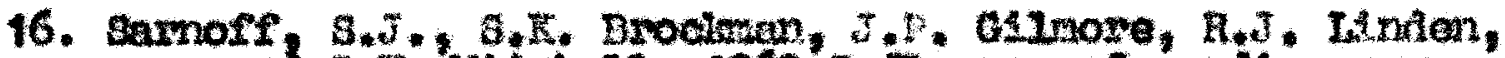

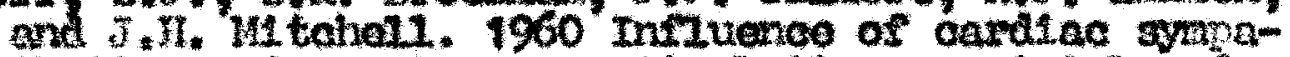
tivotios and vacal nome stimuation on atrial and vontricular aynaies. Cireuiatsion Ros. Os 1108-1122.

17. Sarnofe, 3.J., 1960 Discusaton of Jahnofer's paver on control control of caretac function. Irytar. Rev. 40. Supp. 4, $232-245$.

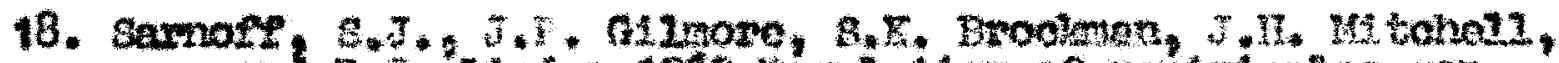

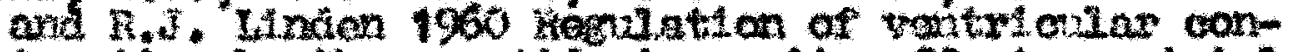

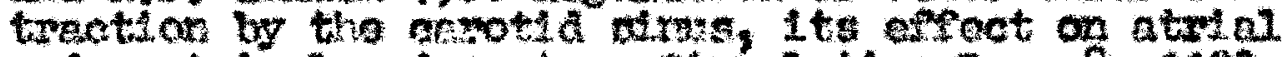
and vontricular dyneatica. Cireuation nos. 3: 11231136.

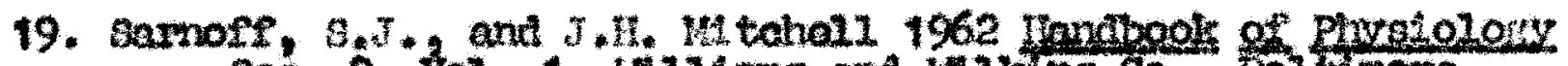

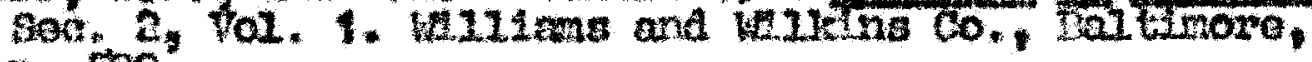

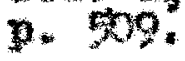

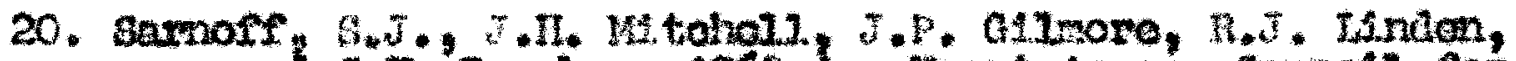

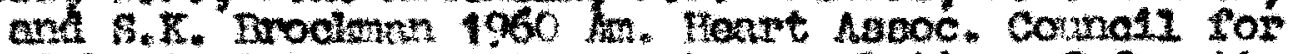

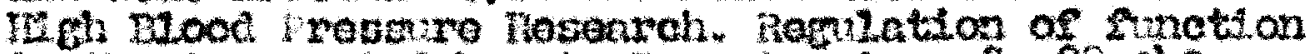

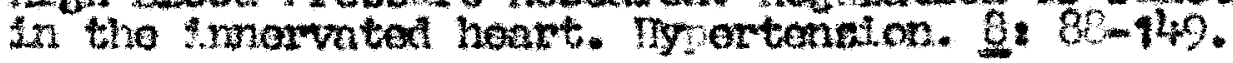

21. Schow, A.M. 1961 Lootricn act: vt ty of the hoart, chav. 10,

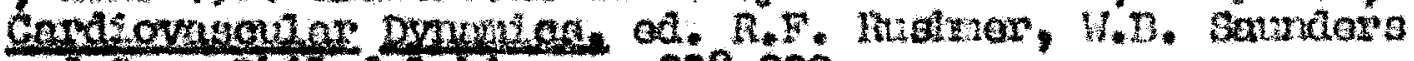
and co., Phiadal ha, p. 238 -299. 
22. Schor, A.1. 1902 landool of thretologr soc. 2 , Vol. 1. M11sans and Wikns co., Battrore, p. 267-322.

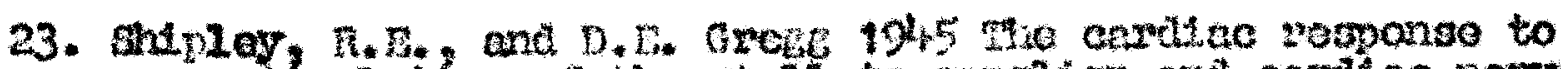

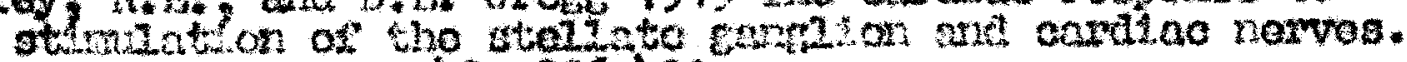
An. J. Thestot. 143: $396 \mathrm{mot}$.

24. Unor, R.I., ad U.C. Randall 196/ Atwowntmonar ros-

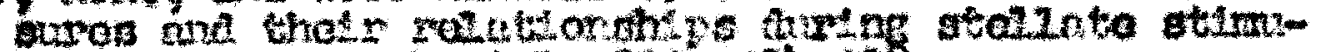
20tion. Ar. I. Thyol. 201 . $134-130$.

25. Wallace, A.C. 1963 symathots inmuances on condrotion in tho intnot honet. (Abst) Pod. Troe. 22. 570 .

26. Hulace, A.6., and 8.J. Samofy 1964 sefoots of cardine

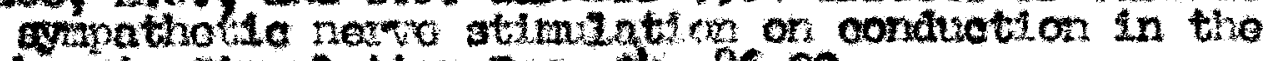
nowt. corrutation nos. 14, 26-92.

27. Wggors, C.t. 1927 The interretation of the intravontrient-

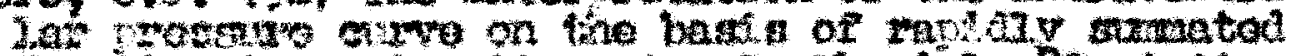
Iractionete comtraction. An. J. Phystol. Bon 1-11. 


\section{A. povar BWWar}

The thos: gubmettod by charios B. Osadjon has been rond and approvet by throo matbers of the sactuty of the cromate school.

The rinat contes hewe been estrulned by the diroctor of thic

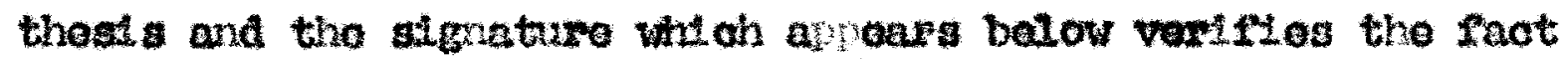
that any nocessary changes have boen incomoratod, and that the theal is is now given final aphroval with refowence to contant, fozra and nomanceal accuracy.

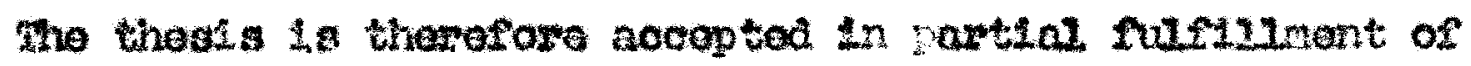

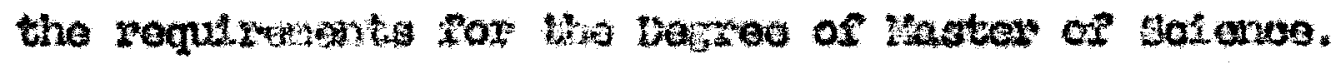

$$
5-2=64
$$

Date

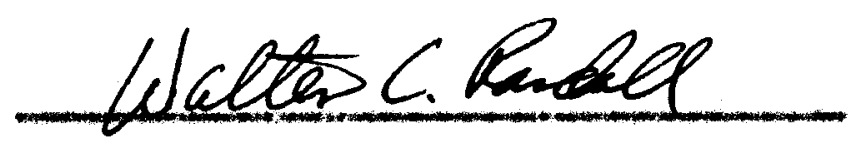

stenotoxo of saveor 